\title{
TAXONOMIC REVISION OF THORACOSAURUS BAHIENSIS MARSH, 1869, A SUPPOSED GAVIALOIDEA (REPTILIA, CROCODYLIA) FROM CRETACEOUS DEPOSITS OF THE RECÔNCAVO BASIN, BRAZIL
}

\author{
RAFAEL G. SOUZA \\ Laboratório de Sistemática e Tafonomia de Vertebrados Fósseis, Setor de Paleovertebrados, Depto. de Geologia e \\ Paleontologia, Museu Nacional/UFRJ, Quinta da Boa Vista, s/nº , 20940-040, \\ Rio de Janeiro, RJ, Brazil.rafelsouz@gmail.com \\ DOUGLAS RIFF \\ Laboratório de Paleontologia, Instituto de Biologia, Universidade Federal de Uberlândia, 38400-902, Uberlândia, \\ Minas Gerais, Brazil.driff2@gmail.com \\ ALEXANDER W. A. KELLNER \\ Laboratório de Sistemática e Tafonomia de Vertebrados Fósseis, Setor de Paleovertebrados, Depto. de Geologia \\ e Paleontologia, Museu Nacional/UFRJ, Quinta da Boa Vista, s/nº , 20940-040, \\ Rio de Janeiro, RJ, Brazil. kellner@mn.ufrj.br
}

\begin{abstract}
In the Recôncavo Basin, Bahia State, Samuel Allport and latter Charles F. Hartt collected several fossils, being some of them attributed to reptile teeth. Based on the morphotypes of these teeth Othniel C. Marsh nominated two species, the first with "delicately wrinkled surface" as Crocodylus hartti (currently Sarcosuchus hartti), and the second based on teeth with "strong continuous striae, and coarse riblets" as Thoracosaurus bahiensis, this latter will be the focus of this work. Marsh did not designate any holotype and, thus, the five teeth collected and described by Allport became the type series and subsequently the syntypes of the species. However, these are currently lost. Comparing the diagnoses of $T$. bahiensis with the type species of the genus and with others crocodyliformes as well as spinosaurids, we noted that the supposed autapomorphy of the species is highly variable. Therefore, we propose that T. bahiensis should be considered as nomen dubium.
\end{abstract}

Key words: Recôncavo Basin, Bahia, Cretaceous, Thoracosaurus bahiensis, Reptilia, taxonomic revision.

\section{INTRODUCTION}

During the middle to the end of the XIX century, the Cretaceous deposits from the Brazilian Imperial Province of Bahia - now State of Bahia - interested many famous researchers at the time, such as Orville A. Derby from the Museu Nacional in Rio de Janeiro, Charles F. Hartt from United States of America, and Samuel Allport from London (Mawson \& Woodward, 1907). The field activities of those researchers resulted in the discovery of the first reptiles from the Recôncavo Basin that were collected in two localities called Fort Montserrat and Plataforma (Allport, 1860).
In his study, Allport (1860) illustrated several specimens, including nine reptilian teeth that he separated in two morphotypes, both attributed to crocodylomorphs. Four that composed the first morphotype were characterized by having a "delicate wrinkled surface" (Allport, 1860, pl. XVI, figs. 1-3,5), while the remaining five of the second morphotype presented strong and continuous striae, with "coarse riblets" (Allport, 1860, pl. XV, fig. 5; pl. XVI, figs. 4,6-8).

Some years latter (1864-65) the Thayer Expedition, which had the participation of the geologist C. F. Hartt and the paleontologist L. Agassiz, made an extensive exploration on the Northeast Brazil, recovering a great quantity of reptilian fossils from outcrops near the Bahia and San Francisco Railway, most of them actually located on the south portion of Salvador city (Mawson \& Woodward, 1907; Freitas, 2002).

Marsh (1869) studied the teeth collected by Allport (1860) and some undescribed specimens collected by Charles Hartt, erecting the species Crocodylus hartti for the first morphotype and Thoracosaurus bahiensis for the second one. Since Marsh (1869) did not illustrate any material, he relied heavily on the illustration published by Allport (1860) and did not designate holotypes.

Some year later, Mawson \& Woodward (1907) relocated both species to the genus Goniopholis Owen, 1841, previously known from Europe and North America. Those authors further referred a partial lower jaw and osteoderms to Goniopholis hartti (Marsh, 1869), a species later moved to the genus Sarcosuchus Broin \& Taquet, 1966 (see Buffetaut \& Taquet, 1977).

Goniopholis bahiensis (Marsh, 1869) was relocated again in the genus Thoracosaurus Leidy, 1852 by Roxo (1935), who also referred a vertebra, now lost, and some additional teeth 
to this species. Until now, this material has not been studied further. The only other specimen referred to Thoracosaurus bahiensis Marsh, 1869 is a procoelous vertebra from the Cretaceous deposits of the Bauru Group (Huene, 1929). However, as pointed out by Mezzalira (1989) this resulted from a misunderstanding and there is no evidence of this species in those deposits.

In the present paper we present a taxonomic review of Thoracosaurus bahiensis. Unfortunately, the type series (Allport, 1860, pl. XV, fig. 5; pl. XVI, figs. 4,6-8) could not be located during this study and might be lost. Other teeth referred to Thoracosaurus bahiensis collected by the Thayer Expedition are presently deposited in British Museum (Woodward, 1888 - currently Natural History Museum) London, and were also not revised during this research. Thus we made our inference based on the material MN 1281-V, which could represent the teeth described by Roxo (1935). Abbreviations: MN-V, Museu Nacional, Coleção de Paleovertebrados, Rio de Janeiro, Brazil; NHMUK, Natural History Museum United Kingdom, London, England.

\section{GEOLOGICAL SETTING}

Allport (1860) collected the Thoracosaurus bahiensis teeth from the Fort Montserrat outcrop. According to him this deposit is formed by a succession of conglomerates, sandstones and sandy shale. Such sequence of facies, as well the modern geologic maps of the locality (around $12^{\circ} 55^{\prime} \mathrm{S} ; 38^{\circ} 31^{\prime} \mathrm{W}$ ) allows to recognize the prograding deltaic sediments of the Ilhas Group of the Recôncavo Basin as the source of the specimens described by Allport (1860). The Ilhas Group is part of the Sequence K30 of the Rift Supersequence of Silva et al. (2007) and was aged as late Hauterivian-early Barremian.

\section{DESCRIPTION}

The fixation of an explicit type for a new species name is mandatory only after 1999 , following the Article 16.4 of the International Code of Zoological Nomenclature (ICZN). For early taxonomic literature the Code determines that all material the descriptions and/or illustrations were based on is considered syntypic whether or not it still exists (ICZN Article 72.4.1). Therefore, the teeth of the Thoracosaurus bahiensis type series are necessarily classified as syntypes of the species. However, they might be lost until the development of the present work. Here we describe four teeth from the Recôncavo Basin (MN 1281-V, Figure 1), which present the features described by Allport (1860) and Marsh (1869). In general, aspect those teeth are conical and slightly recurved. None is complete, lacking either the basal part or the apex, or, in some of them, both. The enamel, however, is well preserved, having a dark brown color. Despite some differences in size, their morphological features are very similar and all could potentially represent the same taxon.

The first tooth (Figures 1A-C) is the tallest at $24 \mathrm{~mm}$ in length. It lacks both the tip of the apex and the root, and has a curved crown. Basally, the surface gets brighter in color, suggesting that it broke on the transition between the crown and the root. This allows estimation of the length of the complete crown at $30 \mathrm{~mm}$. Well-marked carinae are present on both sides (Figure 1A). The enamel presents some wellmarked longitudinal ridges that are more evident in the middle portion of the crown, disappearing near the apex (Figures 1A-B). The transverse section is sub-circular (Figure 1C).

The second tooth (Figures 1D-F; $19 \mathrm{~mm}$ ) is more complete but also appears to have been broken at the transition of the crown and the root. It shows about the same degree of curvature. Overall present the same morphology as the first tooth (Figures 1D-E), differing mainly by having a shorter anterior carina that does not reach the base of the tooth and by having a slightly more circular transverse section (Figure 1F). Another difference is the longitudinal ridges that, although present, are more tenuous (Figures 1D-E). At the apex, the enamel is not present on one side, suggesting the presence of a wear facet.

The third tooth (Figure 1G) is $13 \mathrm{~mm}$ long and, despite its smaller size, shows the same features as the previous ones, with a circular transverse section. It also apparently shows a developed wear facet.

The last tooth (Figure $1 \mathrm{H}$ ), is the smallest one at $9 \mathrm{~mm}$ and, as the others, shows the well-marked carinae on both sides. The transverse section is circular and the ridges tend to be less marked as the other teeth.

\section{DISCUSSION AND CONCLUSION}

The genus Thoracosaurus was always thought to belong to a diversified group found in Late Cretaceous-early Paleocene marine deposits of North America, Europe and northern Asia (see Brochu, 2004). In the extensive revision of Thoracosaurs made by Brochu (2004) many species were synonymized or treated as nomen dubium, however this revision was focused on North Hemisphere species thus nothing was said about Thoracosaurus bahiensis. Antunes (1964) pointed out about the uncertain affinity of this Brazilian form, advocating that the presence of a genus typically encountered in marine deposits in fluvial layers seemed doubtful. Riff et al. (2012) commented about the possibility that Thoracosaurus bahiensis might include more than one taxon.

Thoracosaurus neocesariensis (de Kay, 1842), type species of the genus, bears conical, curved teeth, with fine longitudinal ridges (Leidy, 1865), which are similar to those of Thoracosaurus bahiensis. Despite some slight differences, such as having the longitudinal ridges on the medial portion of the crown more intensively marked (e.g. Marsh, 1869), several other groups show a basic dental morphology similar to the species of the Recôncavo. Dyrosaurids, for example, also have elongated and striated teeth with developed carinae (e.g. Cope, 1886; Barbosa et al., 2008) such as in Hyposaurus derbianus Cope, 1886 (Figure 2). Antunes (1994) described some isolated teeth from Miocene deposits of Western Europe with basically the same features, including carinae and fine longitudinal ridges that he referred to Gavialis Oppel, 1811. 


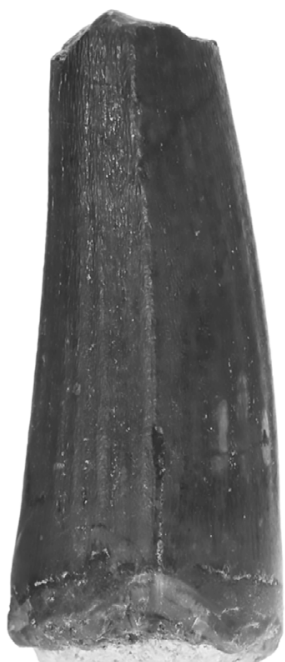

A
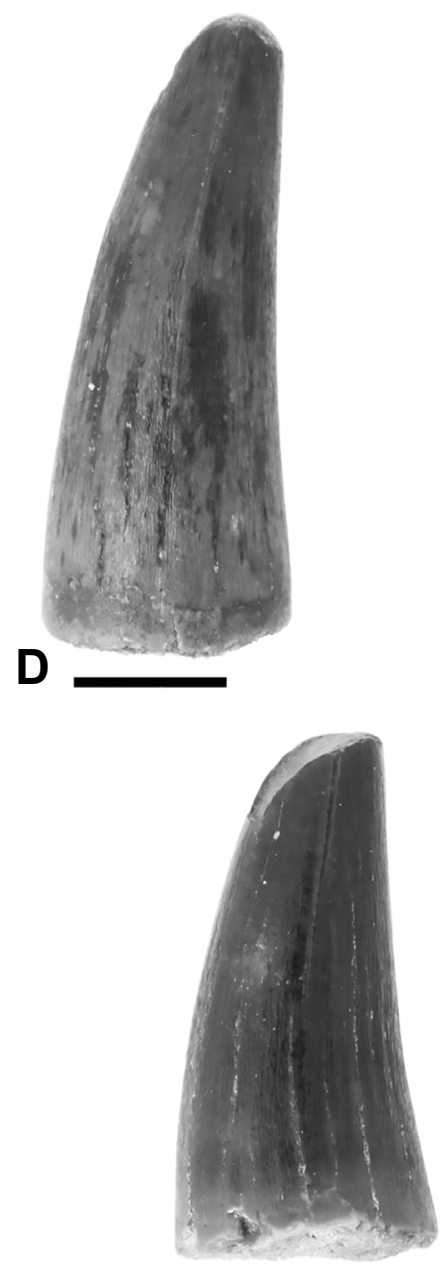

G
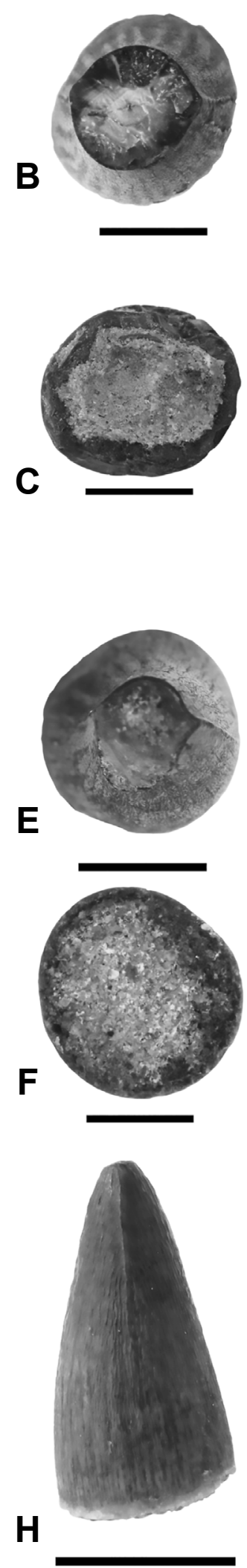

Figure 1. Thoracosaurus bahiensis teeth (MN 1281-V). A, tooth one in lateral view; $\mathbf{B}$, tooth one in apical view; $\mathbf{C}$, tooth one in transverse section; D, tooth two in lateral view; $\mathbf{E}$, tooth two in apical view; $\mathbf{F}$, tooth two in transverse section; $\mathbf{G}$, tooth three in lateral view; $\mathbf{H}$, tooth four in lateral view. Scale bars $=5 \mathrm{~mm}$.

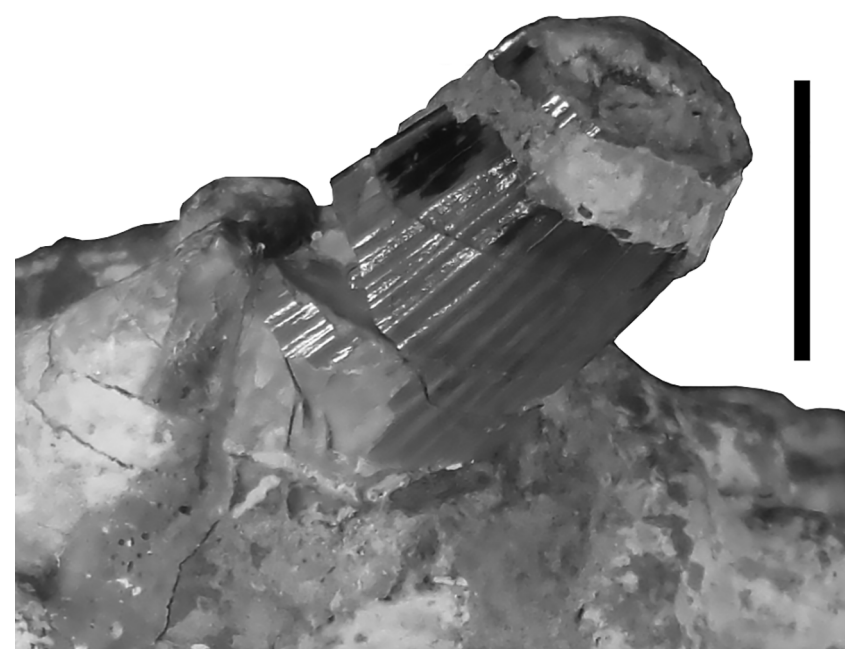

Figure 2. Hyposaurus derbianus (NHMUK PV R 8672); zoom on mandibular tooth elucidating the presence of longitudinal ridges along the tooth. Scale bar $=5 \mathrm{~mm}$.

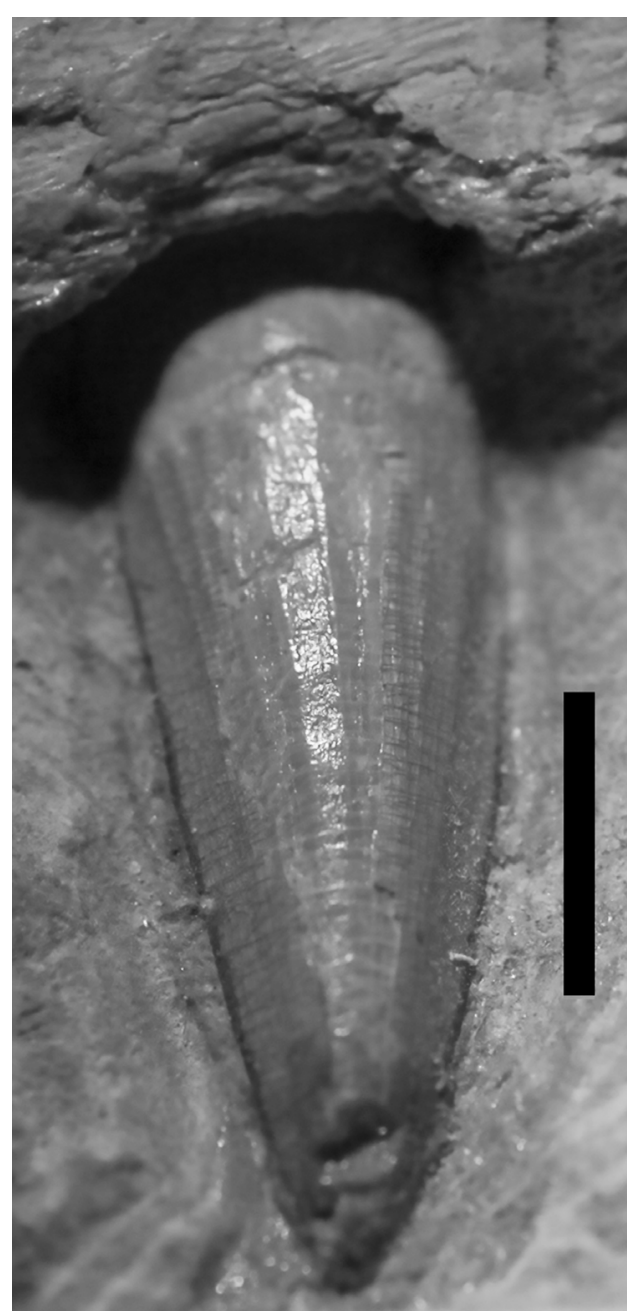

Figure 3. Irritator challengeri (SMNS 58022); zoom on mandibular tooth elucidating the presence of well marked longitudinal ridges at the base disappearing at the apex. Scale bar $=5 \mathrm{~mm}$. 
Other groups with similar configuration of teeth are the spinosaurids. For example, Irritator challengeri Martill, Cruickshank, Frey, Small, Clarke, 1996 and Angaturama limai Kellner \& Campos, 1996 from the Early Cretaceous (AptianAlbian) Romualdo Formation (see stratigraphic discussion in Kellner et al., 2013); shows slightly curved conical teeth with a rounded transverse section and longitudinal ridges (Figure 3). However, Irritator and Angaturama bear fine and short enamel "wrinkles" (Kellner \& Campos, 1996; Sues et al., 2002), as is the case of other spinosaurids (e.g. Sereno et al.,1998; Kellner et al., 2011) that are not present in the Thoracosaurus bahiensis.

From the discussion above it is clear that the features that were used to diagnose Thoracosaurus bahiensis (Marsh, 1869; Roxo, 1935) are widespread within several reptilian groups, particularly crocodylomorphs. The comparatively short teeth suggest that the material MN $1281-\mathrm{V}$ is consistent with several crocodylomorph groups, but one cannot specify which. Due to the scarcity of the specimens and the absence of an anatomical feature or combination of characters that could be regarded as unique leads us to consider this species as nomen dubium.

\section{ACKNOWLEDGEMENTS}

We would like to thank L. Steel (Natural History Museum) for access the specimen of Hyposaurus and D.D.R. Henriques (Museu Nacional/UFRJ) for help during the examination and study of the specimens. We thank to geologist F. Simbras (PETROBRAS), for the discussion about the geological setting of the Recôncavo Basin. We also thank O. Grillo (MN/UFRJ) for the pictures of the specimen and C.A. Brochu (University of Iowa) and D. Pol (Museo Paleontológico Egidio Feruglio) for several suggestions on earlier draft of this paper.

\section{REFERENCES}

Allport, S. 1860. On the discovery of some fossil remains near Bahia in South America. Quarterly Journal of the Geological Society of London, 16:263-266. doi:10.1144/GSL.JGS.1860.016.01-02.36

Antunes, M.T. 1964. Les Tomistoma (reptiles) et leur évolution. Instituto 'Lucas Mallada', Cursillos y Conferencias, 9:171-173.

Barbosa, J.A.; Kellner, A.W.A.; Viana, M.S.S. 2008. New dyrosaurid crocodylomorph and evidences for faunal turnover at the K-P transition in Brazil. Proceedings of the Royal Society B, 275:1385-1391. doi:10.1098/rspb.2008.0110

Brochu, C.A. 2004. A new gavialoid crocodylian from the Late Cretaceous of eastern North America and the phylogenetic relationships of thoracosaurs. Journal of Vertebrate Paleontology, 24:610-633. doi:10.1671/02724634(2004)024[0610:ANLCGC]2.0.CO;2

Buffetaut, E. \& Taquet, P. 1977. The giant crocodilian Sarcosuchus in the Early Cretaceous of Brazil and Niger. Paleontology, 20:203-208.

Cope, E.D. 1886. A contribuition to the vertebrate paleontology of Brazil. Proceedings of the American Philosophical Society, 23:1-21.
Freitas, M.V. 2002. Charles Frederick Hartt, um naturalista no império de Pedro II. Belo Horizonte, UFMG/Humanitas, 282 p.

Huene, F. von. 1929. Los saurisquios y ornitisquios del Cretácico argentino. Anales del Museo de la Plata, 2:1-196.

International Commission on Zoological Nomenclature. 1999. International Code of Zoological Nomenclature. $4^{\text {th }} \mathrm{ed}$. London, International Trust for Zoological Nomenclature and the British Museum of Natural History, [Effective 1 Jan 2000]

Kellner, A.W.A.; Azevedo, S.A.K.; Machado, E.B.; Carvalho, L.B. \& Henriques, D.D.R. 2011. A new dinosaur (Theropoda, Spinosauridae) from the Cretaceous (Cenomanian) Alcântara Formation, Cajual Island, Brazil. Anais da Academia Brasileira de Ciências, 83:99-108. doi:10.1590/S0001-37652011000100006

Kellner, A.W.A. \& Campos, D.A. 1996. First Early Cretaceous theropod dinosaur from Brazil with comment on Spinosauridae. Neues jahrbuch für Geologie und Paläontologie, 199:151-166.

Kellner, A.W.A.; Campos, D.A.; Sayão, J.M.; Saraiva, A.A.F.; Rodrigues, T.; Oliveira, G.; Cruz, L.A.; Costa, F.R.; Silva, H.P \& Ferreira, J.S. 2013. The largest flying reptile from Gondwana: a new specimen of Tropeognathus cf. T. mesembrinus Wellnhofer, 1987 (Pterodactyloidea, Anhangueridae) and other large pterosaurs from the Romualdo Formation, Lower Cretaceous, Brazil. Anais da Academia Brasileira de Ciencias, 85:113-135. doi:10.1590/S0001-37652013000100009

Leidy, J. 1865. Cretaceous reptiles of the United States. Smithsonian Contributions to Knowledge, 192:1-135.

Marsh, O.C. 1869. Notice of some new reptilian remains from the Cretaceous of Brazil. American Journal of Sciences and Arts, 47:1-3. doi:10.2475/ajs.s2-47.141.390

Mawson, J. \& Woodward, A.S. 1907. On the Cretaceous formation of Bahia (Brazil), and on vertebrate fossils collected therein. Quarterly Journal of the Geological Society of London, 63:128-139. doi:10.1144/GSL.JGS.1907.063.01-04.11

Mezzalira, S. 1989. Os fósseis do Estado de São Paulo. São Paulo, Instituto Geológico, $142 \mathrm{p}$.

Riff, D.; Souza, R.G.; Cidade, G.M.; Martinelli, A.G. \& Souza-Filho, J.P. 2012. Crocodilomorfos: a maior diversidade de répteis fósseis do Brasil. Terrae, 9:12-40.

Roxo, M.G.O. 1935. Revalidação de Thoracosaurus bahiensis e considerações sobre a edade da Serie da Bahia. Boletim do Museu Nacional, 12:59-72.

Sereno, P.C. et al. 1998. A long-snouted predatory dinosaur from Africa and the evolution spinoraurids. Science, 282:1298-1302. doi:10.1126/science.282.5392.1298

Silva, O.B.; Caixeta, J.M.; Milhomem, P.S. \& Kosin, M.D. 2007. Bacia do Recôncavo. Boletim de Geociências Petrobras, 15:423-431.

Sues, H.; Frey, E.; Martill, D.M. \& Scott, D.M. 2002. Irritator challengeri, a spinosaurid (Dinosauria: Theropoda) from the Lower Cretaceous of Brazil. Journal of Vertebrate Paleontology, 22:535-547. doi:10.1671/0272-4634(2002)022[0535:ICASDT] 2.0.CO;2

Woodward, A.S. 1888. Notes on some vertebrate fossils from the Province of Bahia, Brazil, collected by Joseph Mawson, Esq., F.G.S. Journal of Natural History, 6:132-136. doi:10.1080/00222938809460891

Received in March, 2015; accepted in October, 2015. 